\title{
WASTE APPLICATION OF SEAWEED (EUCHEUMA COTTONII) ON PLANT GROWTH AND RESULTS OF MUSTARD (BRASSICA JUNCEA L.)
}

\author{
${\text { suriyani }{ }^{1}, \text { Ramal Yusuf }}^{2}$, Abd.Syakur ${ }^{3)}$ \\ ${ }^{1)}$ Agrotechnology Program, Faculty of Agriculture, Tadulako University, Palu, E-mail :Suriyanilabungasa@yahoo.com \\ ${ }^{2)}$ Faculty of Agriculture, Tadulako University, Palu, E-mail :ryusufs@ untad.ac.id
}

\begin{abstract}
Seeing the importance of consuming vegetables and increasing of public demand each day, to increase the maximum production using the fertilizer is one of the solutions, either organic fertilizers or inorganic fertilizers. The objective of this study is to determine the effect of seaweed Eucheuma cottonii waste application on growth and yield of mustard. This study was conducted on January and February 2016. Located in Sidondo, district torch and Seed Technology Laboratory Sciences, Tadulako University, Palu, Central Sulawesi. This study was conducted using a randomized block design (RBD), with treatment consisting of R0 (control), R1 (20\% of waste seaweed), R2 (40\% of waste seaweed), R3 (60\% of waste seaweed), R4 (80\% of waste seaweed) and R5 (100\% of waste seaweed). Each treatment was repeated four times so that there are 24 experimental units. The results showed that the treatment of waste RO seaweed significantly affect the growth and yield of mustard. R5 (100\% of waste seaweed) generating plant height, leaf number, fresh weight, dry weight, better than other treatments.
\end{abstract}

Keywords: Mustard, Seaweed, Waste.

\section{INTRODUCTION}

Horticulture cultivation is one of the mainstay for agriculture sector. This can be seen from the demand of horticultural crops that increase every year. Along with the increasing standard of living in Indonesia, the need for food, especially staple foods such as fruits and vegetables will increase (Sudjianto, 2001).

Vegetable is very important for people's health. The nutritional value of daily food can be improved by eating vegetable, because vegetable is a source of vitamins, minerals, vegetable protein, and of course fiber. According to the results of the Nutrition seminar in 1963 and the Workshop Of Food of 1968, every Indonesian requires $150 \mathrm{~g}$ of clean weight / person / day in the diet. (Hendro Sunarjono, 2003).

Mustard (Brassica junceaL) Is one of the horticultural crop of vegetables used its young leaves. Besides be used as a vegetable material, mustard leaf can also be used for treatment (Cahyono, 2003).

The obstacle faced on the cultivation of mustard plants is the low soil organic matter, so it less support the growth of plants. Thus it is necessary to add organic material by giving organic fertilizer. Organic fertilizers, such as liquid fertilizers, contain the macro and micro nutrients needed for plant growth, and are expected to increase the yield of mustard plants.

Seaweed Eucheuma cottonii consists of microscopic (small shape) and macroscopic (large shape). This macroscopic type is known as seaweed (Poncomulyo et al, 2006).

One type seaweed type is Eucheuma cottonii which is the largest brown algae in the tropical seas. This seaweed has an abundance and a very high distribution, there are almost in all the sea territorial of Indonesia. (Atmadja et al. 1996) in general, 
the seaweed Eucheuma cottonii has not been widely known and utilized. Yet from several studies, it was reported that this has a high enough nutrient content, such as protein and some essential minerals (Mursyidin et al., 2002). This seaweed contains growth regulators (ZPT) (Yusuf, et al 2014). Basmal (2010) reported in Seaweed eucheuma cottonii contained ZPT auxin (IAA) of $112.47 \mathrm{ppm}$, and Zeatin of 77.72 ppm. Referring to the Basmal (2010) research result, the extraction process can decrease the ZPT level in Seaweed waste.

Seaweed has macro and micro nutrients which are quite complete. The prospect of seaweed utilization as organic fertilizer specially in the class of phaeophyceae (brown algae) which can be used as organic fertilizer which are many in Indonesia sea that have not been used.

Now people have changed to consume organic vegetables to avoid poisoning caused by the use of inorganic / chemical fertilizers. With an abundance of seaweed it is expected to produce organic liquid fertilizer which is good for soil health, plants, and environment.

\section{RESEARCH METHODS}

The research was conducted from January to February 2016. Located at Green House, Sidondo Seed Hall and at Seed Technology Science Laboratory, Tadulako University, Palu, Central Sulawesi.

The tools used in this research were bucket, sprayer, polybeg, scales, measuring instruments, caliper, documentation camera and stationery. The materials used were the seeds of mustard, liquid organic fertilizer from seaweed waste, water, as a treatment.

The study used Randomized Block Design (RAK) consisting of 6 treatments in 4 groups, the treatment consisted of:

$\begin{array}{lll}\text { R0 } & = & \text { Control } \\ \text { R1 } & = & 20 \% \text { of Seawed waste } \\ \text { R2 } & = & 40 \% \text { of Seawed waste }\end{array}$

R3 $=60 \%$ of seawed waste

$\mathrm{R} 4=80 \%$ of seawed waste

R5 $=100 \%$ of seawed waste

Each treatment was repeated 4 times so that there were 24 experiments Linear model from Rancngan Random Group as follows:

$$
Y i j=\mu+\tau i+\beta j+\varepsilon i j
$$

$$
\begin{aligned}
\text { for } \mathrm{i} & =1,2,3,4,6 \\
\mathrm{j} & =1,2,3, \ldots
\end{aligned}
$$

description :

Yij = observation value at the of $\mathrm{i}$ treatment of the j-group;

$\mu \quad=$ common middle value (middle population value);

$\tau \mathrm{i}=$ the effect of the $\mathrm{i}-$ treatment additive;

$\beta \mathrm{j}=$ the influence of $\mathrm{j}$ - group additives;

cij = experimental error on the treatment of the $\mathrm{j}$ - group;

\section{Implementation}

\section{Eucheuma cottonii seaweed extraction}

Dried seaweed was then extracted. The procedures of making the extract of seaweed were : firstly, the seaweed was blended until the powder passes 60 mesh, then the seaweed powder taken 100 gram inserted into the frizer temperature $-20^{\circ}$ for 20 minutes, then removed and then mixed with 2 liters of aquades, and heated with temperature $75^{\circ} \mathrm{C}$ for 2-3 hours, then lifted and chilled then filtered, extract that did not pass filter considered as $100 \%$ of seaweed waste, and then diluted according to treatment.

Data Analysis. To know the effect of treatment on observation parameters, then every observation was done the statistical analysis (test F0,05). If it has real impact, then it must be done Tukey test (BNJ $0,05)$.

\section{RESULTS AND DISCUSSION}

\section{Results}

The Number of Leaves, The result of BNJ test shows that the seaweed waste treatment had significant effect on the number 
mustard leaves. Average number of leaves at ages 14, 24 and 34 HST can be seen in Table 1.

The result of BNJ 0,05 test (Table 1 ) shows that at age 14 HST, $80 \%$ of seaweed waste (R4) shows higher leaf number of $8.25 \mathrm{~cm}$. This treatment is different from other treatments, except on treatment (R0) and (R3). At the age of 24 HST shows a higher leaf number of 12.25 with $100 \%$ treatment of seaweed waste (R5), this treatment was not different from other treatment, but different from treatment (R0), while at age 34 HST shows higher leaf number 16,75 with $100 \%$ treatment of seaweed waste (R5) treatment was different from other treatment, but different from treatment (R0) and (R1).

Table 1. Average Number of Mustard Plant Leaves (strand) on Seaweed Waste Fertilizer.

\begin{tabular}{cccc}
\hline Treatment & \multicolumn{3}{c}{ The Number of Leaves (Strand) } \\
& 14 HST & 24 HST & 34 HST \\
\cline { 2 - 4 } & $5.00_{\mathrm{a}}$ & $8.25_{\mathrm{a}}$ & $12.00_{\mathrm{a}}$ \\
\hline $\mathbf{R}_{\mathbf{0}}$ & $6.25_{\mathrm{b}}$ & $10.25_{\mathrm{b}}$ & $13.50_{\mathrm{a}}$ \\
$\mathbf{R}_{\mathbf{1}}$ & $6.75_{\mathrm{b}}$ & $11.0_{\mathrm{b}}$ & $14.25_{\mathrm{b}}$ \\
$\mathbf{R}_{\mathbf{2}}$ & $6.00_{\mathrm{a}}$ & $11.75_{\mathrm{bc}}$ & $14.50_{\mathrm{b}}$ \\
$\mathbf{R}_{\mathbf{3}}$ & $8.25_{\mathrm{bc}}$ & $11.25_{\mathrm{b}}$ & $15.25_{\mathrm{b}}$ \\
$\mathbf{R}_{\mathbf{4}}$ & $6.50_{\mathrm{b}}$ & $12.25_{\mathrm{bc}}$ & $16.75_{\mathrm{bc}}$ \\
$\mathbf{R}_{\mathbf{5}}$ & $\mathbf{1 . 0 7}$ & $\mathbf{1 . 6 0}$ & $\mathbf{1 . 4 1}$ \\
\hline $\mathbf{B N J = 5 \%}$ &
\end{tabular}

Description : Average Numbers Followed by Same Letter in the Same Column, Do Not Differ on the $5 \%$ BNJ test,

Tabel 2. Average Mustard Plant Height on Seaweed Waste Fertilizer.

\begin{tabular}{cccc}
\hline \multirow{2}{*}{ Treatment } & \multicolumn{3}{c}{ Plant Height (cm) } \\
\cline { 2 - 4 } & $\mathbf{1 4}$ HST & 24 HST & 34 HST \\
\hline $\mathbf{R}_{\mathbf{0}}$ & $9.75_{\mathrm{a}}$ & $18.50_{\mathrm{a}}$ & $29.00_{\mathrm{a}}$ \\
$\mathbf{R}_{\mathbf{1}}$ & $11.25_{\mathrm{b}}$ & $22.58_{\mathrm{b}}$ & $33.58_{\mathrm{b}}$ \\
$\mathbf{R}_{\mathbf{2}}$ & $10.80_{\mathrm{ab}}$ & $21.92_{\mathrm{b}}$ & $32.67_{\mathrm{b}}$ \\
$\mathbf{R}_{\mathbf{3}}$ & $11.09_{\mathrm{b}}$ & $22.34_{\mathrm{b}}$ & $33.34_{\mathrm{b}}$ \\
$\mathbf{R}_{\mathbf{4}}$ & $11.75_{\mathrm{bc}}$ & $23.17_{\mathrm{b}}$ & $34.17_{\mathrm{b}}$ \\
$\mathbf{R}_{\mathbf{5}}$ & $12.00_{\mathrm{bc}}$ & $24.00_{\mathrm{bc}}$ & $34.75_{\mathrm{bc}}$ \\
\hline BNJ = 5\% & $\mathbf{0 . 8 0}$ & $\mathbf{1 . 9 0}$ & $\mathbf{2 . 0 5}$ \\
\hline
\end{tabular}

Description : Average Numbers Followed by Same Columnt, Do Not Differ on the $5 \%$ BNJ test.
Plant Height. The result of BNJ test shows that the seaweed waste had significant effect to the mustard height. Average plant height at 14, 24 and 34 HST can be seen in Table 2.

Result of BNJ 0,05 test (Table 2) shows that at age 14 HST treatment of $100 \%$ of seaweed waste (R5) shows higher mustard height as high as $12,00 \mathrm{~cm}$, this treatment was not different from other treatment except treatment without using waste seaweed (R0). At 24 HST the treatment of $100 \%$ of seaweed waste (R5) shows a higher leaf number of 24.00. This treatment was not different from treatment (R1), (R2), (R3), and (R4) ), but different from (R0), whereas at age 34 HST $100 \%$ pearl of seaweed waste (R5) indicated higher plant height as high as $34.75 \mathrm{~cm}$, this treatment was not different from other treatment except (R0) treatment.

Fresh Weight. The result of BNJ test shows that seaweed waste has real effect to fresh weight of mustard plant. Average fresh weight at ages of 14, 24 and 34 HST can be seen in Table 3 .

Dry Weight. The result of BNJ test shows that the seaweed waste treatment had a very significant effect on dry weight of mustard plant. Average dry weight at ages of 14, 24 and 34 HST can be seen in Table 4.

Tabel 3. Average Mustard Plant Fresh Weight on Seaweed Waste Fertilizer.

\begin{tabular}{ccc}
\hline Treatment & Average & BNJ 5\% \\
\hline $\mathbf{R}_{\mathbf{0}}$ & $13.88_{\mathrm{a}}$ & \\
$\mathbf{R}_{\mathbf{1}}$ & $2.2_{\mathrm{b}}$ & \\
$\mathbf{R}_{\mathbf{2}}$ & $16.95_{\mathrm{a}}$ & $\mathbf{5 . 7 9 \%}$ \\
$\mathbf{R}_{\mathbf{3}}$ & $21.75_{\mathrm{b}}$ & \\
$\mathbf{R}_{\mathbf{4}}$ & $17.9_{\mathrm{b}}$ & \\
$\mathbf{R}_{\mathbf{5}}$ & $30.43_{\mathrm{bc}}$ & \\
\hline
\end{tabular}

Description : Average Numbers Which Followed by Same Letter in the Same Column, Do Not Differ On BNJ test 5\% 
Tabel 4. Average Mustard Plant Dry Weight on Seaweed Waste Fertilizer

\begin{tabular}{ccc}
\hline Treatment & Average & BNJ \\
\hline $\mathbf{R}_{\mathbf{0}}$ & $1.51_{\mathrm{a}}$ & \\
$\mathbf{R}_{\mathbf{1}}$ & $2.35_{\mathrm{b}}$ & \\
$\mathbf{R}_{\mathbf{2}}$ & $1.73_{\mathrm{a}}$ & $\mathbf{0 . 6 6} \%$ \\
$\mathbf{R}_{\mathbf{3}}$ & $2.20_{\mathrm{b}}$ & \\
$\mathbf{R}_{\mathbf{4}}$ & $2.18_{\mathrm{a}}$ & \\
$\mathbf{R}_{\mathbf{5}}$ & $3.43_{\mathrm{bc}}$ & \\
\hline
\end{tabular}

Description: Average Numbers Which Followed by Same Letter in The Same Column, Do Not Differ On BNJ test 5\%.

Result of BNJ 0,05 test (Table 4) shows that the treatment of $100 \%$ of seaweed waste (R5) shows the dry weight of the heaviest plant was $3.43 \mathrm{~g}$, this treatment was different from other treatment, but different from (R0) (R2) and (R4) treatment.

\section{Discussion}

Seaweed fertilizer application with various doses gave a very real effect on plant height, leaf number, fresh weight, and dry weight.

The variation in plant height after 14 days planting to 34 days after planting continued to increase and each treatment gave a real different effect, this is because the giving of seaweed waste can increase the growth of the plant. At the age of 14 days after planting until 34 days after planting the treatment of seaweed waste fertilizer showed a higher result that was $100 \%$ compared with other treatment.

Seaweed-based organic fertilizer has advantages over other organic fertilizers, namely in terms of high growth hormone. This hormone is intended to stimulate growth in plants so that plants can grow, be fruitful or flower more quickly, more or greater. The content of ZPT in liquid organic fertilizer of each seaweed produced can be seen from the treatment of seaweed waste (100\%), (Bakti Bariyanto Sedayu et al 2014).

Soil is a natural growing medium that provides nutrients for plant survival.
To make plants producing maximally, the soil should be maintained, errors in soil processing can cause the damage to the soil, consequently it can reduce the production of plants. The productivity of soil in producing agricultural products depends on the ability of a soil to provide balanced nutrients in accordance with the needs of the plant. So the provision of organic fertilizer is needed to increase the nutrient reserves in the soil, improve soil structure and increase the content of soil organic matter. Its effects on soil chemical properties that can improve soil $\mathrm{pH}$, increase $\mathrm{C}$-organic content and increase cation exchange capacity (CEC) soil because organic material has greater cation absorption than clay colloids and can release phosphate $(\mathrm{P})$ from phosphate $(\mathrm{P})$ fixed to P-available for plants (Sudirja et al., 2006).

According to Sutejo (2002), organic fertilizer has an important function compared to inorganic fertilizers that can loosen the surface layer of soil (topsoil), increase the population of microorganisms, enhance absorption and water storage, which overall can increase soil fertility. Organic matter and organic fertilizer are still needed because organic and organic fertilizers are more concerned with the chemical properties of the soil because it has an important role such as preventing iron and aluminum toxicity on sour reacting soils and can increase the availability of phosphate in the soil, an increase in humus levels in the soil will increase the cation exchange capacity (CEC).

\section{CONCLUSION AND SUGGESTION}

\section{Conclusion}

The application of seaweed waste had a significant effect on the growth and yield of mustard plants. The treatment of $100 \%$ of seaweed waste at 34 HST resulted in the highest plant height of $16.75 \mathrm{~cm}$, the highest number of leaves were 34.75 pieces, the heaviest fresh weight was $30.43 \mathrm{~g}$ and the heaviest dry weight was $3.43 \mathrm{~g}$, better from other treatments. 


\section{Suggestion}

It is suggested that there should be further research on the use of seaweed waste fertilizer with the comparison of other organic fertilizer with different doses of mustard plant.

\section{REFERENCES}

Agustina, 2001. Penanaman dan Pemeliharaan Rumput Laut (Eucheuma cottoni ) di Desa Nusi kecamatan Padaido Kabupaten Bia Numfor, Irian Jaya (Skripsi)

Anggradireja, Jaha. T dkk, 2010. Rumput Laut Cet. S, Jakarta : Penerbit Swadaya

Asian. L . 1998. Budidaya Rumput Laut Jogjakarta : Kanisius.

Bakti Berlyanto Sedayu, I Made Suci Erawan, dan Lutfi Assadad. (2014). Pupuk cair dari Rumput Laut Eucheuma cottonii, sargassum sp. Dan Gracilaria sp. Menggunakan proses pengomposan.

Cahyono,B. 2003. Teknik dan Strategi Budi Daya sawi Hijau. Yayasan Pustaka Nusantara, Yogyakarta.

Ditjen, AKH.,W: 2004 Rumput Laut Jenis dan morfologinyaDepartemen Pendidikan Nasional. Jakarta.

Handajunti,S.1999 Membuat Pupuk Organik Cair. Agromedia Pustaka. Jakarta.

Haryanto, E, T. Suhartini, E. Rahayu, 2003. Sawi dan Selada. Jakarta. Penebar Swadaya.

Hendro, Sunarsono. 2003. Bertanam 30 Jenis Tanaman Sayur, Jakarta; Penebar Swadaya.

Heru dan Yovita, 2003. Diakses Http://id.Wikipedia.org/Wiki/Kimchi.

Heru, P dan H, I, Yovita. 2003. Hidroponik Sayuran Semusim Untuk Hobi dan Bisnis. Gramedia, Jakarta.

Indriani,2004. Membuat Kompos Secara Kilat Penebar Swadaya . Jakarta.

Kurniadi, A. 1992. Sayuran Yang Digemari. Jakarta: Harian Suara Tani.

Margiyanto. 2007. Budidaya Tanaman Sawi. Penebar Swadaya. Jakarta.

Munir, w.S.A. Kadi;Sulistijo dan Rahmaniar, 1996. Pengenalan Jenis-jenis Rumput Laut Indonesia. Puslitbang Oseonologi. LIPI Jakarta.

Murbandono, H.L., 2008. Membuat Kompos. Penebar Swadaya. Jakarta.

Poncomulyo, T, Maryani, H. \& Kristiani, L. 2006. Budidaya dan Pengolahan Rumput Laut. Jakarta : Agromedia Pustaka.

Rahmaniar E. Dan Sitanggang.M.2006. Taklukan Penyakit Dengan Klorofil Alfalfa, Agromedia Pustaka, Jakarta.

Rukman, 2002.Contoh-bab-2 penulisan ilmiah. Diakses http:// www. bimbingan. org 
Rukmana, 2002. Bertanam Petsai dan Sawi. Kanisius, Yogyakarta.

Sunarsono, 2003. Bio Teknologi Hasil Laut. PKSPL. IPB. Edisi 1. P64-70.

Yudharta, 2010. Tanaman Sawi. Tersedia di http:// Tanaman Sawi << community Aji chrw-95\%. Htm.( Diakses 12 mei 2014 ).

Yusuf, R, Kristiansen, P ., Syakut, A., Mas'ud, H., and Hawalina, 2015, Detecting Plant Grouth Regulator In Seaweeds Using Biossay, Proseding of the $1{ }^{\text {st }}$ International Conference on Applied Marine Science and Fishheries Technologi. Hal. 107-112.

Yusuf, R, Kristiansen, p., and N, Warwick, 2012. Potencial Effect Of Plant Growth Regulator In Two Swaweed Products. Acta Hortikultura 958. Hal 133-138. 